Acta Theriologica 45 (1): 35-44, 2000.

PL ISSN 0001-7051

\title{
Diet of the otter Lutra lutra in lake Kerkini and stream Milli-Aggistro, Greece
}

\author{
Eleni GOURVELOU, Nicolaos PAPAGEORGIOU and Christos NEOPHYTOU
}

\begin{abstract}
Gourvelou E., Papageorgiou N. and Neophytou C. 2000. Diet of the otter Lutra lutra in lake Kerkini and stream Milli-Aggistro, Greece. Acta Theriologica 45: 35-44.

Spraints of otter Lutra lutra (Linnaeus, 1758), collected from lake Kerkini and stream Milli during autumn and winter, were examined for prey remains. The overall feeding habits were not similar in the two areas. In Kerkini lake, fish was the most important food item ( $98 \%$ by frequency of occurrence). The most important food species were Lepomis gibbosus, Carassius auratus gibelio and Rutilus rutilus. In Milli stream the most important food items were crayfish (78.4\%) and fish (67.6\%). Mammals proved to be an important food category for otters. They occurred in $20 \%$ of the spraints in the lake Kerkini and $29.7 \%$ of the spraints in the stream Milli.

Department of Forestry and Natural Environment, Laboratory of Wildlife and Freshwater Fisheries, Aristotelian University, 54006 Thessaloniki, Greece

Key words: Lutra lutra, feeding habits, Greece
\end{abstract}

\section{Introduction}

The otter Lutra lutra (Linnaeus, 1758) is today among the rare mammals of Europe with Greece holding one of its largest known populations (Mason and Macdonald 1986). In spite of that, otter is considered as a vulnerable species in the Red Book of threatened vertebrates of Greece (Karandinos 1992).

The activities that have caused this decline include the widespread use of agricultural chemicals and the discharge of industrial wastes which poison the waterways. Wetlands have been drained to increase agricultural production and rivers and streams that were formerly rich with bankside vegetation have been transformed into lifeless drains.

Much information has been published on the feeding behaviour and food habits of the otter in different parts of Europe (Erlinge 1967, 1969, Fairley and Wilson 1972, Hewson 1973, Webb 1975, Jenkins 1980, Jenkins and Harper 1980, Chanin 1981, Erlinge and Jensen 1981, Gormally and Fairley 1982, Adrian and Delibes 1987, Arca and Prigioni 1987, Struyf 1987, Kruuk et al. 1990). However, data on its feeding habits in Greece are missing.

The objective of this study was to investigate the diet of the otter in the lake Kerkini and the stream Milli-Agistron. 


\section{Study area}

Lake Kerkini is a semi-natural wetland used as an irrigation reservoir in northern Greece. It is a wetland of International Importance (according to the Ramsar Convention), Special Protection Area (according to the Directive 79/409/EEC) and Site of Community Importance (according to the Directive 92/43/EEC).

The Lake was created in 1932 after the construction of a dam to prevent floods of the Strymon River. A new dam and higher dikes were installed in 1982. There is a water level fluctuation of $4.5 \mathrm{~m}$ during the year. The surface of the flooded area

Table 1. Fish species of lake Kerkini and the varies from 4500 ha (in autumn-winter) to 7300 bed of the river Strymon. ha (in summer). The water level during the study period varied from $31 \mathrm{~m}$ to $35 \mathrm{~m}$ a.s.l. The mean yearly temperature is $15.4^{\circ} \mathrm{C}$, with mean maxima

\begin{tabular}{ll}
\hline Scientific name & English name \\
\hline Abramis brama & Bream \\
Alburnus alburnus strumicae & Bleak \\
Anquilla anquilla & Eel \\
Aspius aspius & Asp \\
Barbus plebejus cyclolepis & Barbel \\
Carassius auratus gibelio & Crucian carp \\
Chondrostoma vardarensis & Nase \\
Cobitis tainia & Spined loach \\
Cyprinus carpio & Carp \\
Gambusia affinis & Mosquito-fish \\
Gobio gobio bulgaricus & Gudgeon \\
Leuciscus cephalus macedonicus & Chub \\
Lepomis gibbosus & Pumpkinseed \\
Neomacheilus angorae bureschi & Stone loach \\
Perca fluviatilis & Perch \\
Rhodeus seriacus amarus & Bitterling \\
Rutilus rutilus & Roach \\
Scardinius erythropthalmus & Rudd \\
Silurus glanis & Wels \\
Tinca tinca & Tench \\
Vimba melanops & Zahrte \\
\hline
\end{tabular}
of $20^{\circ} \mathrm{C}$ and mean minima of $8.6^{\circ} \mathrm{C}$.

The most common fish species, present in the lake and the Strymon river are given in the Table 1 (Arianoutsou et al. 1986, Economidis 1974). Some species (eel, tench, and perch) disappeared from the wetland many years ago. Although Kerkini is an artificial lake, it is very important as a fish producing wetland. The fish species with large populations are crucian carp, bleak and pumpkinseed. The latter is the only carnivorous fish of the lake and it is assumed to have immigrated from Bulgaria. The stream Milli, where a part of the study was conducted, flows into Agistron stream which is a tributary to the Strymon river. It is $4427 \mathrm{~m}$ long and has a mean width of $7 \mathrm{~m}$. Its mean depth is $35 \mathrm{~cm}$. The stream has a regular flow during the year. The water temperature remains constant at $12-13^{\circ} \mathrm{C}$ throughout the year. The streambed is covered mainly by stones. The vegetation along the banks is very thick, shading more than $75 \%$ of the area. The larger part of the watershed is transformed into cultivated fields for corn and wheat. The most common fish species present in the stream are brown trout, barbel and chub.

\section{Methods}

The determination of the otter diet was carried out by means of the otter spraint analysis. The spraint contains those parts of the food intake that can not be digested (scales, hairs, feathers, bones). Spraints were collected from the two study areas (lake Kerkini, and the stream Milli), over a period of five months, from November 1990 to March 1991. Along the coasts of lake Kerkini, seven standard collection routes, $1 \mathrm{~km}$ each, were established. Spraint collection was achieved by following the same route over three days in the second half of each month. At the banks of Milli stream, three standard collection routes, $700 \mathrm{~m}$ each, were established. This distance was walked during the second half of each month. The old-looking faeces were ignored to ensure that the monthly samples were indeed representative for the otter's diet. Each spraint was put into a plastic bag and marked properly. The samples were removed and dried at air temperature. Dried spraints were stored in plastic bags marked with details of their identity. 
Dried spraints were cleaned before analysing them. Each spraint was put in a plastic pot where water and a few drops of detergent were added. The overnight soaking in this solution, was enough to remove the mucilaginous materials that were bound to the undigested remains. Afterwards, the spraint was washed through a sieve of $0.5 \mathrm{~mm}$ mesh. The food remains were spread on a petri dish, the bottom of which was covered by filter paper and examined under the stereoscope. The identification of invertebrate remains in the spraints was carried out by the use of a reference collection. Fish remains were identified using a reference collection of scales. Fish representative of nearly all species living in the district, were obtained from the fishermen of the area. From each species, a few scales were taken from the area below the lateral line. The scales were cleaned by using thrypsine solution. A small number (5) of the best looking scales were put between two micro slides, making permanent samples. The relationship between age and length of the fish was calculated using the scale method as described by Lagler (1956).

Mammal remains were identified by means of hair morphology (Papageorgiou and Sfougaris 1989). Bones and feathers were identified using a reference collection.

\section{Statistical procedures}

The statistical analysis was done on an IBM Personal Computer using the "SPSS" statistical package.

There are several ways of expressing the data obtained from spraint analysis. In the present study, for each prey category, the number of occurrence, the frequency of occurrence, and the relative frequency were calculated. The number of occurrence $(\mathrm{N})$ is determined as the number of spraints containing a specific prey item. All spraints containing a particular prey, were expressed as a percentage of the total number of spraints collected (frequency of occurrence F\%). The formula used is: $\mathrm{F} \%=(\mathrm{N} / n) \times 100$, where $\mathrm{N}$ is the number of occurrence of each species and $n$ is the total number of spraints analysed.

With relative frequency ( $\mathrm{RF} \%$ ), the number of occurrence of a prey item is expressed as a percentage of the total number of occurrence of all prey items in the whole sample. The formula used is: $\mathrm{RF} \%=(\mathrm{N} / \mathrm{TN}) \times 100$, where $\mathrm{N}$ is the number of occurrence of each species and TN is the total number of occurrence of all prey categories.

One-way analysis of variance was performed to study differences between months for each prey item eaten, using a monthly frequency of occurrence from each standard collection route as the dependent variable and the month as the independent variable. The null hypothesis, that the food of the otter was identical for five months, was tested using the $F$-statistics. When significant differences were found between months, Duncan's multiple range test was used to determine which month differed significantly at the 0.05 level of significance.

\section{Results}

\section{The otter diet in the lake Kerkini}

Results of the otter diet in the lake Kerkini are based on the analysis of 100 spraints containing 207 prey items. The number of occurrence, the frequency of occurrence and the relative frequency of the species taken by otters were calculated (Table 2).

Fish was the most important component of the otter diet, occurring in $98 \%$ of the examined spraints. Fish belonged to two families, Cyprinidae and Centrarchidae. The Cyprinidae, represented by nine species, occurred in $69 \%$ of the spraints, while the Centrarchidae, with one representative species (Lepomis gibbosus), occurred in $57 \%$ of the spraints. Within cyprinids, Carassius auratus and Rutilus rutilus were the most important prey species (frequency of occurrence $24 \%$ and $22 \%$ respec- 
tively). Since Lepomis gibbosus was found to be the most important prey species, its prey size was calculated (Table 3 ).

Mammals were the second most important food category (20\%). Within mammals four families were identified (Table 4). The mammals that could not be identified to species had a frequency of occurrence of $9 \%$.

Birds were comprising $9 \%$ of the otter diet, followed by amphibians and insects ( $3 \%$ respectively). Molluscs and plant materials were of no significance since they formed $2 \%$ of the diet.

Table 2. The composition of the otter diet in lake Kerkini. N - number of occurrence, F\% - frequency of occurrence, $\mathrm{RF} \%$ - relative frequency. The number of spraints per month is 20 .

\begin{tabular}{|c|c|c|c|c|c|c|c|c|}
\hline Food items & $\begin{array}{l}\text { Nov } \\
\text { F\% }\end{array}$ & $\begin{array}{l}\text { Dec } \\
\mathrm{F} \%\end{array}$ & $\begin{array}{l}\text { Jan } \\
\text { F\% }\end{array}$ & $\begin{array}{l}\text { Feb } \\
\text { F\% }\end{array}$ & $\begin{array}{c}\text { Mar } \\
\text { F\% }\end{array}$ & $\begin{array}{c}\text { Total } \\
\mathrm{N}\end{array}$ & $\begin{array}{c}\text { Total } \\
\text { F\% }\end{array}$ & $\begin{array}{l}\text { Total } \\
\text { RF\% }\end{array}$ \\
\hline Abramis brama & 15.0 & 20.0 & 10.0 & 15.0 & 30.0 & 18 & 18.0 & 8.7 \\
\hline Alburnus alburnus strumicae & 10.0 & 0.0 & 0.0 & 0.0 & 0.0 & 2 & 2.0 & 1.0 \\
\hline Aspius aspius & 0.0 & 5.0 & 5.0 & 10.0 & 30.0 & 10 & 10.0 & 4.8 \\
\hline Carassius auratus gibelio & 0.0 & 20.0 & 10.0 & 30.0 & 60.0 & 24 & 24.0 & 11.6 \\
\hline Cyprinus carpio & 10.0 & 5.0 & 15.0 & 10.0 & 10.0 & 10 & 10.0 & 4.8 \\
\hline Lepomis gibbosus & 90.0 & 70.0 & 85.0 & 30.0 & 20.0 & 59 & 59.0 & 28.5 \\
\hline Leuciscus cephalus macedonicus & 0.0 & 0.0 & 0.0 & 25.0 & 20.0 & 9 & 9.0 & 4.4 \\
\hline Rhodeus seriacus amarus & 10.0 & 5.0 & 0.0 & 0.0 & 0.0 & 3 & 3.0 & 1.5 \\
\hline Rutilus rutilus & 10.0 & 0.0 & 20.0 & 35.0 & 45.0 & 22 & 22.0 & 10.6 \\
\hline Scardinius erythropthalmus & 15.0 & 5.0 & 0.0 & 0.0 & 10.0 & 6 & 6.0 & 2.9 \\
\hline Vimba melanops & 5.0 & 5.0 & 0.0 & 0.0 & 0.0 & 2 & 2.0 & 1.0 \\
\hline Unknown & 0.0 & 0.0 & 0.0 & 5.0 & 5.0 & 2 & 2.0 & 1.0 \\
\hline Molluscs & 0.0 & 5.0 & 0.0 & 0.0 & 0.0 & 1 & 1.0 & 0.5 \\
\hline Amphibians & 0.0 & 15.0 & 0.0 & 0.0 & 0.0 & 3 & 3.0 & 1.5 \\
\hline Birds & 25.0 & 10.0 & 0.0 & 5.0 & 5.0 & 9 & 9.0 & 4.4 \\
\hline Mammals & 15.0 & 25.0 & 5.0 & 40.0 & 15.0 & 20 & 20.0 & 9.7 \\
\hline Insects & 10.0 & 0.0 & 5.0 & 0.0 & 0.0 & 3 & 3.0 & 1.5 \\
\hline Seeds & 0.0 & 5.0 & 0.0 & 0.0 & 0.0 & 1 & 1.0 & 0.5 \\
\hline Invertebrates & 5.0 & 10.0 & 0.0 & 0.0 & 0.0 & 3 & 3.0 & 1.5 \\
\hline
\end{tabular}

Table 3. Calculated length of each age class of Lepomis gibbosus.

\begin{tabular}{lcc}
\hline $\begin{array}{l}\text { Classes } \\
\text { of age }\end{array}$ & $\begin{array}{c}\text { Number } \\
\text { of fish }\end{array}$ & $\begin{array}{c}\text { Calculated } \\
\text { length (mm) }\end{array}$ \\
\hline I & 17 & 85 \\
II & 25 & 108 \\
III & 35 & 118 \\
IV & 17 & 124 \\
V & 6 & 131 \\
\hline
\end{tabular}

Table 4. Mammals as a food for otters in the lake Kerkini.

\begin{tabular}{lc}
\hline Food items & $\begin{array}{c}\text { Frequency } \\
\text { of occurrence (\%) }\end{array}$ \\
\hline Soricidae & 3 \\
Leporidae (Oryctolagus) & 1 \\
Arvicolidae (Clethrionomys) & 1 \\
Muridae (Apodemus) & 6 \\
Muridae (Rattus) & 1 \\
Unknown & 9
\end{tabular}


Table 5. Summarized results of the analysis of variance of each prey category in the lake Kerkini. ** - shows highly significant differences, * - shows significant differences, ns - shows no significant differences.

\begin{tabular}{lrc}
\hline Food items & F ratio & Level of significance \\
\hline Abramis & 0.7640 & $0.5513 \mathrm{~ns}$ \\
Alburnus & 2.1111 & $0.0854 \mathrm{~ns}$ \\
Aspius & 3.3070 & $0.0139 *$ \\
Carassius & 7.1929 & $0.0000^{* *}$ \\
Cyprinus & 0.2669 & $0.8986 \mathrm{~ns}$ \\
Lepomis & 12.2696 & $0.0000^{* *}$ \\
Leuciscus & 4.2374 & $0.0034^{* *}$ \\
Rhodeus & 1.3818 & $0.2461 \mathrm{~ns}$ \\
Rutilus & 4.3569 & $0.0028 * *$ \\
Scardinius & 1.5236 & $0.2015 \mathrm{~ns}$ \\
Vimba & 0.7500 & $0.5604 \mathrm{~ns}$ \\
Unknown & 0.7500 & $0.5604 \mathrm{~ns}$ \\
Molluscs & 1.0000 & $0.4116 \mathrm{~ns}$ \\
Amphibians & 3.3529 & $0.0130 *$ \\
Birds & 2.3591 & $0.0589 \mathrm{~ns}$ \\
Mammals & 2.2774 & $0.0666 \mathrm{~ns}$ \\
Insects & 1.3818 & $0.2461 \mathrm{~ns}$ \\
Seeds & 1.0000 & $0.4116 \mathrm{~ns}$ \\
Invertebrates & 1.3818 & $0.2461 \mathrm{~ns}$ \\
\hline
\end{tabular}

Table 6. Duncan's multiple range test for each prey item in the lake Kerkini. Different letters indicate significant differences.

\begin{tabular}{|c|c|c|c|c|c|}
\hline Prey items & November & December & January & February & March \\
\hline Abramis & $0.150 \mathrm{~A}$ & $0.200 \mathrm{~A}$ & $0.100 \mathrm{~A}$ & $0.150 \mathrm{~A}$ & $0.300 \mathrm{~A}$ \\
\hline Alburnus & $0.100 \mathrm{~B}$ & $0.000 \mathrm{~A}$ & $0.000 \mathrm{~A}$ & $0.000 \mathrm{~A}$ & $0.000 \mathrm{~A}$ \\
\hline Aspius & $0.000 \mathrm{~A}$ & $0.050 \mathrm{~A}$ & $0.050 \mathrm{~A}$ & $0.100 \mathrm{~A}$ & $0.300 \mathrm{~B}$ \\
\hline Carassius & $0.000 \mathrm{~A}$ & $0.200 \mathrm{AB}$ & $0.100 \mathrm{AB}$ & $0.300 \mathrm{~B}$ & $0.600 \mathrm{C}$ \\
\hline Cyprinus & $0.100 \mathrm{~A}$ & $0.050 \mathrm{~A}$ & $0.150 \mathrm{~A}$ & $0.100 \mathrm{~A}$ & $0.100 \mathrm{~A}$ \\
\hline Lepomis & $0.900 \mathrm{~B}$ & $0.700 \mathrm{~B}$ & $0.850 \mathrm{~B}$ & $0.300 \mathrm{~A}$ & $0.200 \mathrm{~A}$ \\
\hline Leuciscus & $0.000 \mathrm{~A}$ & $0.000 \mathrm{~A}$ & $0.000 \mathrm{~A}$ & $0.250 \mathrm{~B}$ & $0.250 \mathrm{~B}$ \\
\hline Rhodeus & $0.100 \mathrm{~A}$ & $0.050 \mathrm{~A}$ & $0.000 \mathrm{~A}$ & $0.000 \mathrm{~A}$ & $0.000 \mathrm{~A}$ \\
\hline Rutilus & $0.100 \mathrm{AB}$ & $0.000 \mathrm{~A}$ & $0.200 \mathrm{ABC}$ & $0.350 \mathrm{BC}$ & $0.450 \mathrm{C}$ \\
\hline Scardinius & $0.150 \mathrm{~A}$ & $0.050 \mathrm{~A}$ & $0.000 \mathrm{~A}$ & $0.000 \mathrm{~A}$ & $0.100 \mathrm{~A}$ \\
\hline Vimba & $0.050 \mathrm{~A}$ & $0.050 \mathrm{~A}$ & $0.000 \mathrm{~A}$ & $0.000 \mathrm{~A}$ & $0.000 \mathrm{~A}$ \\
\hline Unknown & $0.000 \mathrm{~A}$ & $0.000 \mathrm{~A}$ & $0.000 \mathrm{~A}$ & $0.050 \mathrm{~A}$ & $0.050 \mathrm{~A}$ \\
\hline Molluses & $0.000 \mathrm{~A}$ & $0.050 \mathrm{~A}$ & $0.000 \mathrm{~A}$ & $0.000 \mathrm{~A}$ & $0.000 \mathrm{~A}$ \\
\hline Amphibians & $0.000 \mathrm{~A}$ & $0.150 \mathrm{~B}$ & $0.000 \mathrm{~A}$ & $0.000 \mathrm{~A}$ & $0.000 \mathrm{~A}$ \\
\hline Birds & $0.250 \mathrm{~A}$ & $0.100 \mathrm{~A}$ & $0.000 \mathrm{~A}$ & $0.050 \mathrm{~A}$ & $0.050 \mathrm{~A}$ \\
\hline Mammals & $0.150 \mathrm{~A}$ & $0.250 \mathrm{~A}$ & $0.050 \mathrm{~A}$ & $0.400 \mathrm{~A}$ & $0.150 \mathrm{~A}$ \\
\hline Insects & $0.100 \mathrm{~A}$ & $0.000 \mathrm{~A}$ & $0.050 \mathrm{~A}$ & $0.000 \mathrm{~A}$ & $0.000 \mathrm{~A}$ \\
\hline Seeds & $0.000 \mathrm{~A}$ & $0.050 \mathrm{~A}$ & $0.000 \mathrm{~A}$ & $0.000 \mathrm{~A}$ & $0.000 \mathrm{~A}$ \\
\hline Invertebrates & $0.050 \mathrm{~A}$ & $0.100 \mathrm{~A}$ & $0.000 \mathrm{~A}$ & $0.000 \mathrm{~A}$ & $0.000 \mathrm{~A}$ \\
\hline
\end{tabular}


In the analysis of variance, it appeared that for the species Carassius auratus gibelio, Lepomis gibbosus, Leuciscus cephalus macedonicus, and Rutilus rutilus, there were highly significant differences between months. In amphibians and Aspius aspius there were significant differences (at 0.05 level of significance), while for the other prey items there were no significant differences (Table 5).

For the taxa where significant differences were detected, (level of significance 0.05), Duncan's multiple range test was performed (Table 6).

\section{The otter diet in the stream Milli}

Results of the otter's diet in the stream Milli are based on the analysis of 37 spraints, containing 79 prey items. The frequency of occurrence and the relative frequency of the species taken by otters were calculated (Table 7).

Crayfish (Crustacea) was the most important food component occurring in $78.4 \%$ of the spraints. Fish comprised $67.6 \%$ of the diet and belonged to the families Salmonidae (62.2\%) and Cyprinidae (5.4\%). The salmonids were represented by one species in the stream, the brown trout (Salmo trutta fario). Rutilus rutilus was the only member of cyprinids that occurred in spraints. The age - length relationship of trout has been calculated using the scale method (Table 8).

Mammals were the third food category, comprising $29.7 \%$ of the diet. The mammal species identified in food remains belonged to the families Muridae $(24.5 \%)$ and Soricidae $(5.4 \%)$. All mice belonged to the genus Apodemus but no further identification was possible. Birds were making up the next food category, comprising $8.1 \%$ of the samples. Molluscs, seeds and plant materials were also recorded.

The analysis of variance showed that for the crayfish there were highly significant differences between months. For the trout there were also significant differences, (Table 9), while for the other prey categories there were not.

Duncan's multiple range test was performed (level of significance 0.05), for the crayfish and trout (Table 10). Concerning the trout, the frequency of occurrence in February differed from the frequency of the other months. The frequencies in

Table 7. The composition of the otter's diet in the stream Milli. N - number of occurrence, F \% frequency of occurrence, $n$ - number of spraints, RF \% - relative frequency of occurrence.

\begin{tabular}{|c|c|c|c|c|c|c|c|c|}
\hline Food items & $\begin{array}{c}\text { November } \\
\begin{array}{c}\mathrm{F} \% \\
n=7\end{array}\end{array}$ & $\begin{array}{c}\text { December } \\
\begin{array}{c}\text { F } \% \\
n=7\end{array}\end{array}$ & $\begin{array}{c}\text { January } \\
\text { F \% } \\
n=7\end{array}$ & $\begin{array}{c}\text { February } \\
\text { F } \% \\
n=8\end{array}$ & $\begin{array}{c}\text { March } \\
\text { F \% } \\
n=8\end{array}$ & $\begin{array}{c}\text { Total } \\
\text { N }\end{array}$ & $\begin{array}{l}\text { Total } \\
\text { F \% }\end{array}$ & $\begin{array}{l}\text { Total } \\
\text { RF \% }\end{array}$ \\
\hline Salmo sp. & 66.7 & 87.5 & 42.9 & 25.0 & 87.5 & 23 & 62.2 & 29.11 \\
\hline Crayfish & 83.5 & 37.5 & 71.4 & 100.0 & 100.0 & 29 & 78.4 & 36.71 \\
\hline Mammals & 66.7 & 37.5 & 0.0 & 12.5 & 37.5 & 11 & 29.7 & 13.92 \\
\hline Molluses & 16.7 & 12.5 & 14.3 & 0.0 & 0.0 & 3 & 8.1 & 3.80 \\
\hline Rutilus rutilus & 0.0 & 12.5 & 14.3 & 0.0 & 0.0 & 2 & 5.4 & 2.53 \\
\hline Birds & 0.0 & 0.0 & 0.0 & 25.0 & 12.5 & 3 & 8.1 & 3.80 \\
\hline Seeds & 0.0 & 0.0 & 42.9 & 0.0 & 0.0 & 3 & 8.1 & 3.80 \\
\hline Plant items & 0.0 & 0.0 & 0.0 & 25.0 & 0.0 & 2 & 5.4 & 2.53 \\
\hline Mosses & 0.0 & 12.5 & 0.0 & 0.0 & 25.0 & 3 & 8.1 & 3.80 \\
\hline
\end{tabular}


Table 8. Calculated length of each age class of Salmo trutta fario.

\begin{tabular}{lcc}
\hline $\begin{array}{l}\text { Classes } \\
\text { of age }\end{array}$ & $\begin{array}{c}\text { Number } \\
\text { of fish }\end{array}$ & $\begin{array}{c}\text { Calculated } \\
\text { length (mm) }\end{array}$ \\
\hline I & 73 & 159 \\
II & 47 & 223 \\
III & 9 & 282 \\
IV & 7 & 305 \\
V & 3 & 327 \\
VI & 1 & 340 \\
VII & 3 & 357 \\
VIII & 2 & 378 \\
\hline
\end{tabular}

Table 9. Summarized results of the analysis of variance in the stream Milli. ** - shows highly significant differences, ${ }^{*}$ - shows significant differences, ns - shows no significant differences.

\begin{tabular}{lcc}
\hline Food items & Fratio & $\begin{array}{c}\text { Level of } \\
\text { significance }\end{array}$ \\
\hline Salmo sp. & 3.0552 & $0.0307 *$ \\
Crayfish & 4.1255 & $0.0083 * *$ \\
Mammals & 2.3784 & $0.0725 \mathrm{~ns}$ \\
Molluscs & 0.5965 & $0.6678 \mathrm{~ns}$ \\
Rutilus rutilus & 0.7378 & $0.5731 \mathrm{~ns}$ \\
Birds & 1.2859 & $0.2962 \mathrm{~ns}$ \\
Seeds & 4.8649 & $0.0035 * *$ \\
Plant items & 2.0901 & $0.1052 \mathrm{~ns}$ \\
Mosses & 1.2859 & $0.2962 \mathrm{~ns}$
\end{tabular}

Table 10. Duncan's multiple range test for all prey items in the steam Milli. Different letters indicate significant differences.

\begin{tabular}{llllll}
\hline Food items & November & December & January & February & March \\
\hline Salmo sp. & $0.66677 \mathrm{AB}$ & $0.8750 \mathrm{~B}$ & $0.4286 \mathrm{AB}$ & $0.2500 \mathrm{~A}$ & $0.8750 \mathrm{~B}$ \\
Crayfisi & $0.8333 \mathrm{~B}$ & $0.3750 \mathrm{~A}$ & $0.7143 \mathrm{AB}$ & $1.0000 \mathrm{~B}$ & $1.0000 \mathrm{~B}$ \\
Mammals & $0.6667 \mathrm{~A}$ & $0.3750 \mathrm{~A}$ & $0.0000 \mathrm{~A}$ & $0.1250 \mathrm{~A}$ & $0.3750 \mathrm{~A}$ \\
Molluscs & $0.1667 \mathrm{~A}$ & $0.1250 \mathrm{~A}$ & $0.1429 \mathrm{~A}$ & $0.0000 \mathrm{~A}$ & $0.0000 \mathrm{~A}$ \\
Rutilusrutilus & $0.0000 \mathrm{~A}$ & $0.1250 \mathrm{~A}$ & $0.1429 \mathrm{~A}$ & $0.0000 \mathrm{~A}$ & $0.0000 \mathrm{~A}$ \\
Birds & $0.0000 \mathrm{~A}$ & $0.0000 \mathrm{~A}$ & $0.0000 \mathrm{~A}$ & $0.2500 \mathrm{~A}$ & $0.1250 \mathrm{~A}$ \\
Seeds & $0.0000 \mathrm{~A}$ & $0.0000 \mathrm{~A}$ & $0.4286 \mathrm{~B}$ & $0.0000 \mathrm{~A}$ & $0.0000 \mathrm{~A}$ \\
Plant items & $0.0000 \mathrm{~A}$ & $0.0000 \mathrm{~A}$ & $0.0000 \mathrm{~A}$ & $0.2500 \mathrm{~A}$ & $0.0000 \mathrm{~A}$ \\
Mosses & $0.0000 \mathrm{~A}$ & $0.1250 \mathrm{~A}$ & $0.0000 \mathrm{~A}$ & $0.0000 \mathrm{~A}$ & $0.2500 \mathrm{~A}$
\end{tabular}

November and January are similar and differ from those of December and March. For crayfish, the frequencies of December and January differed significantly from the others, while the frequencies of November, February, and March were similar.

\section{Discussion}

The two study areas were selected in order to compare the feeding habits of otters in twe localities which differed in fauna composition. Lake Kerkini is dominated by cypririds fish, holding a large population of water birds, whereas the stream Milli is domirated by salmonids fish and crayfish. Fish was the most important food item in the lake, while it was the second one in the stream, after crayfish.

Crayfish plays a primary role in the otter's diet in Milli with high frequency of occurence $(78.4 \%)$. Adrian and Delibes (1987) working in similar habitats in 
Doñana Park in Spain, showed that fish had smaller frequency in areas where Crustacea were present than in other areas. Crayfish in Milli seems to be actively hunted by otters. In studies on captive animals, Erlinge (1968) found that fish were more preferred than crayfish. Nevertheless, crayfish formed a percentage of $80 \%$ of spraints in Spain (Adrian and Delibes 1987) and of $70 \%$ in a river system of western Ireland (McFadden and Fairles 1984). In Greece, in a previous study, crustaceans were recorded in $11.2 \%$ of spraints including those of the freshwater crabs (Macdonald and Mason 1982).

Fish, consisted mainly of salmonids, was the second more important food item for the otters in the stream Milli. In studies around Europe, a large variation in salmonids percentage (from $0 \%$ up to $63 \%$ ) was recorded. These results cannot be compared to the results from Milli because they include salmon species and migratory trout species, as well. In Fiora river in Italy (an area more similar to Milli), salmonids make up 2.9\% of the otter's diet (Arca and Prigioni 1987). Erlinge (1968) noted that otters catch trout with difficulty, and prefer slow - moving fish. In the stream Milli, otters seem to catch trout very easily, due to the fact that the majority of trouts there had escaped from the hatchery and thus were vulnerable to predators. Besides salmonids, cyprinids (Rutilus rutilus) occurred in the otter's diet with a fairly low frequency of occurrence.

By Duncan's multiple range test, it appeared that crayfish was consumed more during December, February and March while trout was consumed more during December and March. It seems that the choice of prey in the stream Milli is determined by availability and vulnerability.

Fish was the most important food category in the lake Kerkini, having the highest frequency in the otter's spraints (98\%). Macdonald and Mason (1982) after analysing spraints from various places in Greece found that fish appeared with lower frequency. The differences can be explained by the different seasons that the two studies were carried out. The present study was carried out in winter while Macdonald's study was conducted in spring. Larger prey diversity during spring is the reason for less fish consumption by otters. This agrees with the results of another study made at Mikri Prespa lake (Delaki et al. 1988), where fish comprised $50 \%$ of the diet during June-September and $90 \%$ in the rest of the year. In Fiora river in Italy, fish occurred in 99.3\% of spraints (Arca and Prigioni 1987).

Cyprinids play a primary role in the otter's diet, probably all year long. They occurred in frequencies higher than those found in Northern Europe but similar to those found in Mediterranean countries (Arca and Prigioni 1987). Moreover, several species of cyprinids were exploited. Ten species were identified; Carassius auratus gibelio, Rutilus rutilus and Abramis brama were the species, more often taken by otters. Similar diversity within the cyprinid family was found in Italy (Arca and Prigioni 1987) and in the lake Mikri Prespa (Delaki et al. 1988).

Lepomis gibbosus (Centrarchidae) had the highest frequency as a single prey species. This species is a native of North America and was introduced in Europe in 
1880 (Neophytou and Giapis 1992). Since then it has dispersed throughout most of Europe.

Through Duncan's multiple range test, it appeared that the species Aspius aspius, Carasssius auratus, Rutilus rutilus and Leuciscus cephalus were consumed more during March. At the beginning of spring the species are moving close to the shores of the lake where the water is shallow, to spawn. At this time, they seem to be more vulnerable to otters. The species Lepomis gibbosus was consumed more from November to January. Pumpkinseed lives in shallow water (Neophytou and Giapis 1992), where it is hunted by otters when the other species are rare in this area. In conclusion, it appears that otters are foraging along the water's edge and the choice of the prey species is determined by their availability.

Besides fish, mammals proved to be an important food category to otters. Mammals occurred in 20\% of the spraints in the lake Kerkini and $29.7 \%$ of the spraints in the stream Milli. Macdonald and Mason (1982) showed that mammals were a supplement to the otter diet in Greece, having an occurrence of $8.7 \%$, while in Italy (Arca and Prigioni 1987) mammals were an inconsiderable food item. In the study made in Mikri Prespa, mammals were also a food item of minor importance.

A wide variety of mammal species occurred in the otter diet. In the stream Milli, the mammals eaten by otters belonged to two families. The majority of the eaten mammals were mice. In the lake Kerkini, four families were represented. Most mammals are probably caught as they come down to the waterside to drink and this may explain the remains of big species (rabbits) in spraints.

Birds make up a small proportion of the diet $(9 \%$ and $8.1 \%$ in the lake and the stream, respectively). Similar proportions were recorded in Greece (Macdonald and Mason 1982). Mason and Macdonald (1986), suggested that birds are taken more often in eutrophic lakes and during summer.

Amphibians appeared only in spraints coming from the lake Kerkini, in very low frequency (3\%). Higher consumption of amphibians was recorded in Italy $(9.4 \%)$ and Spain (18.3\%). Higher frequencies can also be found in Greece, but only during spring and summer when amphibians are spawning and active.

Reptiles did not appear in spraints since they are in hibernation during winter. Insects, molluscs and vegetative items, occurred in low frequencies and they are considered to be incidentally taken by otters.

Most of the fish taken by otters were small and young. For the species Lepomis gibbosus, the size class of $84.5 \mathrm{~mm}$ was predominant in spraints. Erlinge (1968) stated that fish under $90 \mathrm{~mm}$ were difficult to catch for otters, but Adrian and Delibes (1987) found that occasionally entire spraints were made up of very small fish ( $1 \mathrm{~g}$ in weight). In the lake Kerkini the length of Lepomis, eaten by otters, ranged from $84.5 \mathrm{~mm}$ up to $130.8 \mathrm{~mm}$. In the stream Milli, otters seem to prefer fish (trout) up to two years old and up to $223 \mathrm{~mm}$ long. Mason and Macdonald (1986), noticed that otters catch trout with difficulty, especially large ones. This can explain why otters eat young trout in Milli stream and why crayfish in the same area has been consumed in so high numbers. 


\section{References}

Adrian M. and Delibes M. 1987. Food habits of the otter (Lutra lutra) in two habitats of the Doñana national park S.W. Spain. Journal of Zoology, London 212: 399-406.

Arcá G. and Prigioni C. 1987. Food of the otter on the Fiora River (Italy). Acta Theriologica 32: 134-140.

Arianoutsou M., Vlachos Ch., Kapetanyiannis G., Kokkinakis A., Kokkini S., Letsios B., Galaskas G. and Hallman B. 1986. Lake Kerkini. Delineation program of the wetlands of Ramsar Convention. Ministry of Environment, Athens: 1-126. [In Greek]

Chanin P. 1981. The diet of the otter and its relation with the feral mink in two areas of Southwest England. Acta Theriologica 26: 83-95.

Delaki E. G. Kotzageorgis V. Ioannidou and Stamopoulos A. 1988. A study of otters in lake Mikri Prespa, Greece. I.U.C.N. Otter Specialist Group, Bulletin 3: 12-16.

Economidis P. S. 1974. [Morphological, systematic and zoogeographical study of freshwater fishes in E. Macedonia and Thraki]. Doctorate thesis. Aristotelian University of Thessaloniki, Thessaloniki. [In Greek]

Erlinge S. 1967. Food habits of the fish-otter (Lutra lutra) in South Swedish habitats. Viltrevy 4 : 371-443

Erlinge S. 1968. Food studies on captive otters (Lutra lutra). Oikos 19: 259-270.

Erlinge S. 1969. Food habits of the otter (Lutra lutra) and the mink (Mustela vison) in the Sweden. Oikos 20: 1-7.

Erlinge S. and Jensen H. 1981. The diet of otters (Lutra lutra) in Denmark. Nature 19: 161-165.

Fairley J. S. and Wilson S. C. 1972. Autumn food of otters (Lutra lutra) on the Agivey River, County Londonderry, Northern Ireland. Journal of Zoology, London 166: 468-469.

Gormally M. J. and Fairley J. S. 1982. Food of otters (Lutra lutra) in a freshwater lough and an adjacent brackish lough in the west of Ireland. Journal of Zoology, London 186: 463-474.

Hewson R. 1973. Food and feeding habits of otters (Lutra lutra) at Loch Park, north-east Scotland. Journal of Zoology, London 170: 143-162.

Jenkins D. 1980. Ecology of otters in northern Scotland. I. Otter (Lutra lutra) breeding and dispersion in mid-Deeside, Aberdeenshire in 1974 -79. Journal of Animal Ecology 49: 713 -735.

Jenkins D. and Harper R. J. 1980. Ecology of otters in northern Scotland. II. Analysis of otter (Lutra lutra) and mink (Mustela vison) faeces from Deeside, N.E. Scotland in 1977-78. Journal of Animal Ecology 49: 737-754.

Karandinos M. 1992. [The red data book of threatened vertebrates of Greece]. Hellenic Zoological Society, Athens:1- 35. [In Greek]

Kruuk H., Wansink D. and Moorhouse A. 1990. Feeding patches and diving success of the otter (Lutra lutra) in Shetland. Oikos 57: 68-72.

Lagler K. F. 1956. Freshwater fishery biology. 2nd edition. William C. Brown Co., Dubuque, Iowa: 1-421.

Macdonald S. M. and Mason C. F. 1982. Otters in Greece. Oryx 16: 240-244.

MacFadden Y. M. T. and Fairley J. S. 1984. Food of the otters (Lutra lutra) in an Irish limestone river system with special reference to the crayfish Austrapotamobius pallipes (Lereboullet). Journal of Life Science Dublin Society 5: 65-67.

Mason C. F. and Macdonald S. M. 1986. Otters: Ecology and Conservation. Cambridge University Press, Cambridge: 1-236.

Neophytou C. and Giapis A. J. 1992. A study of the biology of Lepomis gibbosus L. in the lake Kerkini. Geotechnic Scientific Issue 3: 12- 20. [In Greek with English summary]

Papageorgiou N. and Sfougaris A. 1989. [Identification of mammals of Greece by hair morphology] Aristotelian University of Thessaloniki, Thessaloniki: 1 - 83. [In Greek]

Struyf K. 1987. Biologie de la loutre. Zoo anvers 52: 27-33.

Webb J. B. 1975. Food of the otter (Lutra lutra) on the Somerset Levels. Journal of Zoology, London 177: 486-491.

Received 25 June 1997, accepted 2 November 1999. 